\title{
Location Based Service for improving Chabot Disaster Management Evacuator Palu
}

\author{
Muhammad Syaifur Rohman ${ }^{1}$ \\ ${ }^{1}$ Program Studi Teknik Informatika, Fakultas IImu Komputer, Universitas Dian Nuswantoro, \\ Semarang \\ 1JI. Imam Bonjol No.207, Pendrikan Kidul, Kec. Semarang Tengah, Kota Semarang, Jawa \\ Tengah 50131, Indonesia \\ email: 'syaifur@dsn.dinus.ac.id
}

\section{ARTICLE INFO}

Article history:

Received 07 February 2020

Received in revised form 06 Maret 2020

Accepted 27 July 2020

Available online 31 July 2020

\begin{abstract}
The devastating earthquake that struck Palu on the island of Sulawesi last September ripped through the Earth's crust at a rare high speed, scientists have found. When the disaster is over, many natural disaster victims need immediate help. The call center provided is usually busy with services and complaints from victims of natural disasters. The greater the impact of natural disasters, the more information services that must be carried out. By using CEPAT chatbot for disaster evacuation in Palu, information about evacuation place can be given to victim by access it. Then when the victim shares their location, CEPAT will give the nearest evacuation place information using LBS improvement Chabot.
\end{abstract}

Keywords: Location Based Service, Chatbot, Disaster Management, Artificial Intelligent, Geographic Information System

\section{Introduction}

Hasil dari penelitian sejak tahun 1905 - 2005 kota palu dan sekitarnya berdasarkan catatan telah terlanda gempa dengan magnitudo > 4,5 SR lebih dari 10 (sepuluh) kejadian, berdasarkan kondisi topografi, geologi dan seismologi wilayah Kota Palu sangat potensial mengalami kerusakan akibat gempa termasuk bencana sekunder (tsunami, likuefaksi dan longsoran tebing) seperti pernah terjadi pada tanggal 20 Mei 1938. Ini terjadi karena menurut catatan ahli Teknik sipil di Indonesia, $70 \%$ wilayah Indonesia berada pada daerah rawan bencana gempa. Bencana alam telah menjadi tugas kita bersama untuk mengatasinya. Ada beberapa fase dalam penanggulangan bencana alam seperti preparedness, response, response dan mitigation [1]. Begitu juga terjadinya bencana alam yang terjadi saat 28 September 2018 di Palu. Bencana alam yang terjadi begitu cepat sehingga membuat preparedness sistem yang sudah disediakan sebelumnya jadi kurang berfungsi padahal begitu penting [2]. Sehingga setelah bencana alam yang berupa tsunami dan gempa bumi melanda palu, banyak kerugian dialami para korban bencana alam.

Menurut Badan Nasional Penanggulangan Bencana Indonesia (BNPB) pada tanggal 21 November 2018 tercatat 2.256 orang meninggal dunia, sebanyak 1.309 orang hilang, 4.612 orang luka-luka dan 223.751 orang mengungsi di 122 titik. Hasil perhitungan sementara terhadap

Received February 07, 2020; Revised Maret 06, 2020; Accepted July 27, 2020 
kerugian dan kerusakan akibat bencana berdasarkan data per 20/10/2018, mencapai lebih dari 13,82 triliun rupiah. Saat bencana telah selesai melanda, banyak korban bencana alam ini yang membutuhkan pertolongan langsung. Karena banyak tempat tinggal yang hancur, rumah sakit dan peralatan kesehatan tidak dapat beroperasi, toko-toko kebutuhan pokok yang tutup bahkan sampai terjadi tindak kriminal yang terpaksa terjadi karena dampak bencana ini [2].

Dengan adanya bencana alam yang terjadi di daerah palu dan sekitarnya pemerintah bahkan relawan sukarela tidak tinggal diam. Penanganan bencana setelah terjadinya bencana adalah proses evakuasi. Menurut [1] proses evakuasi adalah suatu satu fase dari response disaster management dimana evakuasi ini dilakukan dalam periode atau waktu yang berdekatan setelah bencana itu terjadi. Sehingga korban bencana alam sangat membutuhkan pertolongan pertama [3] seperti logistic berupa makanan, minuman, pakaian layak pakai, pelayanan medis darurat, transportasi sampai dengan posko-posko untuk para korban bencana.

Bantuan yang datang selain dari pemerintah Indonesia dan relawan sukarela dari dalam negeri juga banyak bantuan yang datang dari luar negeri [4]. Bantuan bantuan ini nantinya akan disalurkan ke posko-posko yang disediakan. Sehingga korban bencana akan mendapatkan bantuannya saat berada di posko. Menurut data yang dikumpulkan dari mahasiswa Universitas Gadjah Mada yang berasal dari daerah Palu [5] ada 22 posko yang disediakan dan 19 rumah sakit untuk penanganan kesehatan. Namun ternyata jumlah tersebut masih jauh tidak sebanding dengan titik pengungsian penduduk yang mencapai 429 jumlahnya. Bisa dibayangkan bantuan logistik yang hanya dipusatkan di beberapa posko didistribusikan ke titik pengungsian yang besar jumlahnya.

Untuk mengatasi permasalahan ini biasanya ditunjuk beberapa koordinator yang mewakili titik pengungsian untuk mendapatkan informasi terkait dengan distribusi bantuan dari posko. Namun data yang didapat ini adalah data yang didapat setelah selang waktu yang lama setelah terjadinya bencana. Padahal evakuasi harus dilakukan dengan segera saat atau dalam waktu yang berdekatan setelah bencana terjadi. Otomatis informasi yang diketahui terlebih dahulu adalah lokasi-lokasi rumah sakit dan kemudian setelah pemerintah dan relawan sukarela turun tangan baru dibangunnya posko-posko. Untuk titik pengungsian biasanya dibangun secara mandiri oleh korban bencana karena belum datangnya bantuan dari pemerintah atau pun sukarela sehingga saat terjadi seperti ini, informasi tentang bantuan yang datang kurang diketahui. Keberadaan posko untuk bantuan yang kurang diketahui pun menjadi masalah tersendiri. Sehingga dengan keadaan yang serba minim informasi ini bisa meningkatkan kurangnya penanganan pertama dalam bencana alam.

Korban bencana yang kurang informasi ini biasanya dipengaruhi oleh jaringan komunikasi yang kurang memadai karena kerusakan yang diakibatkan bencana alam. Setelah adanya jaringan komunikasi, korban bencana alam tidak tahu harus menghubungi ke mana atau mencari tahu informasi dimana. Call center yang disediakan biasanya sibuk dengan layanan dan aduan dari korban-korban bencana alam. Semakin besar dampak bencana alamnya maka akan semakin banyak pelayanan informasi yang harus dilakukan. Sehingga perlu adanya pengganti manusia yang tidak akan mengenal batasan jumlah, waktu dan tenaga layanan.

Saat ini sudah berkembang teknologi layanan informasi pengganti manusia berupa Chatter-bot (Chatbot). Teknologi Chatbot ini diimplementasikan bukan dalam bentuk fisik yang bisa disentuh oleh manusia melainkan disisipkan dengan teknologi media informasi digital yang sudah ada seperti di computer atau smartphone. Layanan informasi yang diberikan tidak akan dibatasi oleh jumlah interaksi, waktu pelayanan bahkan tidak akan mengenal lelah seperti manusia. Sehingga saat terjadinya bencana, layanan Call center melalui chatbot dapat melakukan tugasnya untuk membantu memberikan informasi tentang keberadaan pos bantuan yang diharapkan oleh korban bencana alam.

Location Based Service for improving Chabot Disaster Management Evacuator Palu (Muhammad

Syaifur Rohman) 


\section{Penelitian Terkait}

Pada tanggal 28 September 2018 telah terjadi bencana alam yang menimpa daerah palu sehingga menimbulkan banyak kerugian materi dan korban jiwa. Penanggulangan bencana akhirnya menjadi suatu hal yang sangat penting karena jika dapat diterapkan dengan baik maka kerugian-kerugian materi atau korban jiwa dapat ditekan. Menurut literatur [6] menjelaskan bahwa evakuasi adalah sebuah strategi dalam menangani kasus yang darurat dan memindahkan korban bencana ke tempat yang lebih aman. Penanganan yang cepat dan tepat dalam penentuan rute menjadi hal yang krusial disini. Dalam [7] MCES yang dikembangkan dapat disesuaikan permintaan ke cloud services oleh banyak pengguna sehingga akses pencarian lokasi untuk evakuasi bisa lebih memungkinkan. Karena pada kondisi evakuasi bencana alam, permintaan terhadap cloud services akan melonjak banyak dan kesemuanya membutuhkan proses yang cepat. Penelitian lain untuk Evakuasi DM [8] untuk September 2001 and Philippines Typhoon Haiyan 2013 dengan Intelligent Transportation Systems including Vehicular Ad hoc Networks (VANETs), mobile dan Cloud Computing teknologi. Dengan begitu pentingnya fase evakuasi pada penanggulangan bencana dan diketahui Indonesia adalah negara yang paling rentan terkena bencana alam terutama dengan jumlah populasi penduduk yang begitu banyak, [3] mengembangkan Decision Support System dengan berbasis Web. Walaupun menggunakan studi kasus pada Indonesia, sistem yang dikembangkan oleh penelitian ini bisa digunakan tempat lain. Dengan beberapa penelitian terkait yang direview dapat disimpulkan bahwa proses evakuasi memegang peneranan penting dalam fase reseponse sistem terutama pada penanganan bencana alam.

Walaupun evakuasi untuk bencana alam begitu penting terutama pada fase response, namun pada beberapa paper yang di-review sebelumnya kurang adanya pendekatan terhadap cara teknologi komunikasi yang tepat. [9] Menggunakan salah satu teknologi komunikasi yaitu Natural Language Processing (NLP) pada twitter. Menggunakan algoritma Liner Support Vector Machine pada NLP, penelitian ini menunjukkan 3 kelas utama yaitu damage, no damage, dan not relevant untuk daerah terdampak tertentu. Penggunaan twitter [10] untuk mengumpulkan data juga dilakukan pada krisis antara tahun 2013 sampai 2015 untuk evakuasi terhadap bencana. Penggunaan NLP mengklasifikasi beberapa twitter dari beberapa laporan pengguna. Melalui Algoritma Naïve Bayes, Support Vector Machine dan Random Forest klasifikasi dapat dilakukan. Setelah data diambil biasanya data dari twitter ini diolah dengan metode Sentiment Analisis seperti [11][12]. Selain twitter, penggunaan social media lain seperti Instagram, vine, facebook sampai reddit juga digunakan untuk crisis monitoring [13].

Berbagai penelitian mengatakan bahwa pentingnya penerapan Location Based Service (LBS) menjadi faktor pendukung pertama dalam respon terhadap bencana yang terjadi [14]. Dalam penelitian [15] penggunaan LBS digunakan untuk menandai dimana pengguna berada sehingga bisa memberikan evakuasi yang tepat melalui GPS yang dikirimkan pengguna lalu divisualisasikan dengan OpenStreetMap. Kasus badai Joaquin pada tahun 2015 telah membuat penelitian menerapkan penggunaan tweeter untuk pendistribusian dimana korban bencana berada. Sehingga dengan adanya data data yang diperoleh melalui twitter, kordinat kordinat mereka dapat dilacak lalu dengan penerapan LBS ditampilkan dengan format peta proses evakuasi dapat dilaksanakan dengan maksimal. Bagaimanapun melalui hasil dari penelitian terkait, apapun sumber datanya ketika menggunakan LBS dengan baik maka proses evakuasi dapat memberikan pertolongan saat atau setalah bencana terjadi.

Jadi dari hasil penggunaan NLP pada penelitian terkait terbukti dapat membantu pengenalan maksud, tujuan dan arti pesan korban dalam pemberian penanganan bencana. Sayangnya, jika menggunakan social media yang disebutkan sebelumnya kebanyakan tidak ada komunikasi 2 arah antara relawan dan korban. Penggunaan NLP hanya memproses data yang masuk, artinya hanya menerima informasi saja tanpa memberikan informasi yang belum tentu tepat. Selain itu pada [16] menggunakan social messenger application dapat dilakukan komunikasi 2 arah. Namun komunikasi dengan menggunakan social messenger ini dalam

TRANSFORMATIKA Vol. 18, No. 1, July 2020: 114-122 
evakuasi pada response sistem masih kurang efektif karena masih ada campur tangan manusia yang terbatas waktu dan tenaga. Sehingga dikembangkanlah chatbot yang menggunakan NLP sehingga pemberian evakuasi dapat dilakukan tanpa mengenal waktu dan tanpa mengenal batasan orang yang bekerja didalam-nya karena menggunakan bot. Lalu jika chatbot yang digabungkan dengan teknologi LBS maka chatbot ini akan dapat mengolah informasi selain text sehingga penerimaan atau pemberian informasi terkait dengan evakuasi bencana dapat dimaksimalkan lagi.

\section{Metodologi}

Untuk membuat sebuah chatbot agar mengerti dengan Bahasa yang digunakan oleh manusia ada penjelasan dari arsitektur chatbot mengenai bagaimana caranya bekerja. Walaupun penggunaan bahasa Indonesia wajib di Indonesia namun sering kali karena keberagaman budaya dan bahasa disana sangat bervariasi sehingga Bahasa Indonesia yang digunakan seringkali bercampur dengan kata serapan dari Bahasa daerahnya dan cara penyusunan penggunaan Bahasa Indonesia akhirnya tidak baku. Sehingga untuk menyelesaikan masalah ini, pemilihan keyword akan sangat berpengaruh karena keyword dalam NLP adalah yang membuat bagaimana Chatbot dapat mengerti dan memahami maksud dari interaksi pengguna. Walaupun dalam satu pertanyaan akan menggunakan kata kata yang banyak, chatbot akan memproses keyword yang sesuai dengan pengetahuan yang dimilikinya.

Chatbot dibuat untuk dapat memberikan respon dalam bentuk percakapan teks berbahasa manusia. Mesin yang dimiliki oleh chatbot dilengkapi dengan kata kunci tertentu diambil dari pemrosesan teks bahasa alami (NLP) [17]. Sehingga bisa memiliki output yang didapat oleh pengguna chatbot itu. Sehingga untuk membuat chatbot ini haruslah menyiapkan keyword keyword yang akan dikenali. Interaksi pada chatbot pada dasarnya dibagi menjadi 2 komponen penting, yaitu pertanyaan dan jawaban.

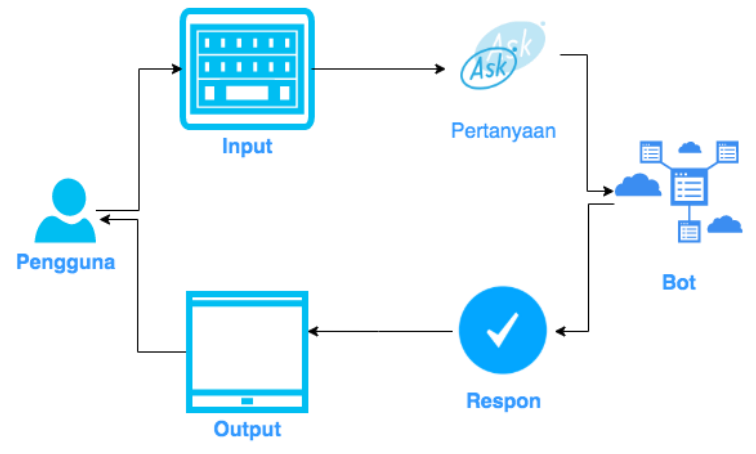

Gambar 1. Arsitektur Chatbot

Pada gambar 1 di atas Arsitektur Mesin Chatbot memiliki beberapa komponen yang saling bekerja untuk dapat memberikan respon berupa output yang ditampilkan kepada pengguna mengenai Input berupa pertanyaannya. Sehingga saat pengguna sedang keadaan untuk mencari informasi yang kritis mengenai posko terdekat, dia tidak perlu memikirkan bagaimana caranya mengakses informasinya namun dia hanya perlu memasukkan input pertanyaan dalam Bahasa Indonesia lalu dari input pertanyaan ini akan ada proses untuk pengenalaan Percakapan dimana informasi informasi disimpan. Lalu jika Input dari pertanyaan bisa sesuai dengan Percakapan maka output respon akan diberikan sesuai dengan topik yang dimaksud oleh pengguna yaitu informasi tentang lokasi posko terdekat dia.

Untuk pembuatan NLP dalam penelitian ini menggunakan agent chatbot yang bernama flowxo.com. Konsep yang diterapkan dalam Chatbot Penanganan Bencana Darurat (CEPAT) ini adalah konsep penggunaan Percakapan untuk memodelkan perilaku Percakapan chatbot. Dalam

Location Based Service for improving Chabot Disaster Management Evacuator Palu (Muhammad

Syaifur Rohman) 
hal ini setiap pokok pembahasan percakapan kita harus memodelkannya. Baik bagaimana pengguna memberikan input, bagaimana chatbot memproses inputan itu, lalu memberikan output yang di inginkan.

\subsection{Memodel Percakapan}

Dalam tujuan penelitian ini chatbot CEPAT harus memberikan tanggapan mengenai dimana lokasi terdekat posko posko bantuan dimana pengguna berada. Saat pengguna membuka chatbot ini haruslah ada sapaan dengan informasi yang jelas dan singkat tentang bagaimana chatbot dapat memberikan informasi posko posko bantuannya. Setelah itu Pengguna harus dispesifikan tentang bagaimana memberikan informasi keberadaannya dalam hal ini CEPAT dibuat untuk dapat menerima share location dari pengguna. Lalu setelah pengguna mengirimkan locationnya maka CEPAT akan memproses sehingga akan memberikan output berupa respon dimana lokasi terdekat posko bantuan.

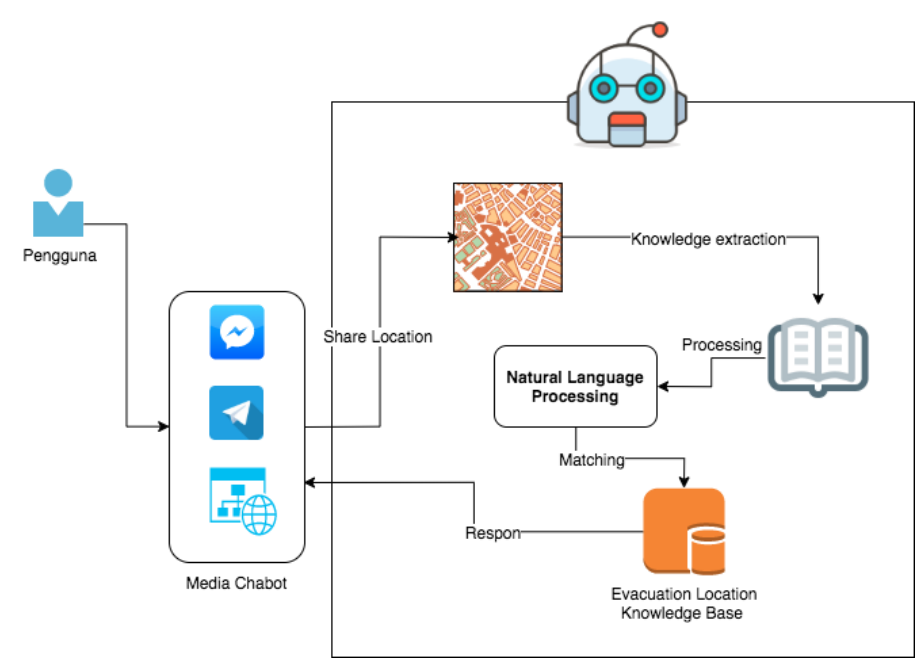

Gambar 2. Arsitektur CEPAT

Berdasarkan gambar 2 mengenai arsitektur CEPAT Pengguna akan memberikan share location dan mendapatkan lokasi lokasi terdekat posko evakuasi. Media interaksi dengan chatbot CEPAT yaitu menggunakan facebook messenger, telegram dan website khusus. Lalu melalui chatbot ini setelah pengguna membuka chatbotnya akan diberikan pesan sapaan tentang bagaimana pengguna mendapatkan informasi lokasi posko. Lalu setelah mendapatkan informasi mengenai cara penggunaan chatbot, pengguna dapat langsung memberikan share location melalui media chatbot yang disediakan. Setelah ini kordinat akan didapat oleh chatbot dan fungsi dari kordinat ini adalah memilihkan lokasi terdekatnya. Namun untuk dapat memberikan spesifik lokasi apa yang diberikan keyword khusus harus disematkan didalamnya yaitu keyword "posko bencana di dekat palu, kota palu, sulawesi tengah" ini dilakukan saat proses konfigurasi chatbot. Kordinat dan keyword sudah dijadikan menjadi satu inputan dengan pengguna dan selanjutnya NLP berusaha mencocokan dengan Evacuation Location Knowledge Base yang sesuai dengan keywordnya sesuai pada tabel 1 .

Table 1. Location Knowledge Base

\begin{tabular}{lc}
\hline \multicolumn{1}{c}{ Nama Lokasi } & Kordinat \\
\hline Posko Utama Tanggap Bencana Pospera Sulteng & $-0.9081419,119.8943963$ \\
Posko SultengBergerak & $-0.8999605,119.8757003$ \\
Posko Bersama As-Sunnah & $-0.9159106,119.8912293$ \\
Baznas Kota Palu & $-0.8973483,119.8613835$ \\
Kantor BPBD Kota Palu & $-0.8989321,119.8916187$ \\
\hline
\end{tabular}

TRANSFORMATIKA Vol. 18, No. 1, July 2020: $114-122$ 
BASARNAS Kota Palu

ACT SULTENG (Aksi Cepat Tanggap Sulawesi Tengah)

Masjid Al Huda ,Posko Sahabat Muslim Surakarta

POSKO BENCANA PMI KOTA PALU
$-0.9081506,119.8982741$

$-0.9188821,119.8839149$

$-0.8706025,119.8325647$

$-0.8768282,119.8262645$

Dengan menggunakan data tersebut nantinya koordinat dari pengguna dapat disesuaikan dan pengguna akan langsung mendapatkan respons dari chatbot melalui media yang dipilih.

\subsection{Impelementasi}

Setelah selesai dalam tahap perancangan arsitektur dan pemodelan percakapan maka implementasi dilakukan untuk pembuatan chatbot CEPAT. Agent yang digunakan berfokus pada percakapan tentang suatu topik, maka dalam topik pemberian informasi lokasi posko bantuan terdekat dari pengguna. Dalam pembahasan sebelumnya percakapan dimulai dari pembuatan sapaan dan pemberian informasi terkait penggunaan chatbot.

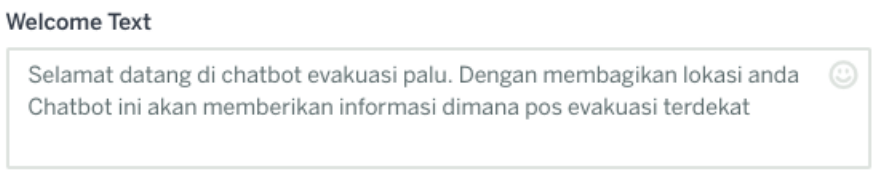

Gambar 3. Konfigurasi Sapaan

Sapaan pada chatbot tertrigger atau muncul otomatis saat pengguna membuka chatbot di medianya. Jika tidak keluar sapaan yang diinginkan, chatbot bisa memberikan pesan ini jika pengguna memberikan input apapun di chatbot.

9. User sends the bot their location Interact > New Fil

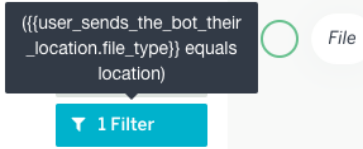

Gambar 4. Konfigurasi Input Pengguna

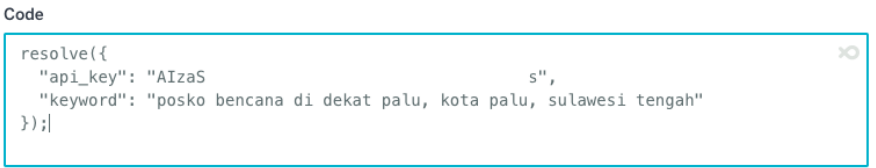

Gambar 5. Konfigurasi Keyword

Pada gambar 3 dan gambar 4 adalah konfigurasi untuk inputan yang dimasukkan pengguna. Gambar 1 mengatur file apa saja yang dapat diproses yakni hanya file sharing location saja. Gambar 4 konfigurasi keyword sehingga hanya keyword "posko bencana di dekat palu, kota palu, sulawesi tengah" yang disematkan kepada peta sehingga hasil lokasinya hanya tentang keyword tersebut. 


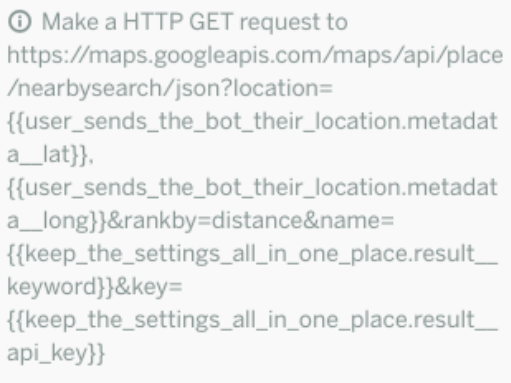

Gambar 6. Konfigurasi API

Dengan menggunakan API dari google map maka proses pencarian lokasi terdekat dapat diketemukan. List lokasi akan tergenerate menyesuaikan dari keyword yang sudah dikonfigurasi sejak awal dan kordinat yang dikirimkan oleh pengguna akan digunakan sebagai ranking dimana lokasi yang paling dekat dengan penggunalah yang akan menempatkan urutan ranking dari pertama sampai terakhir.

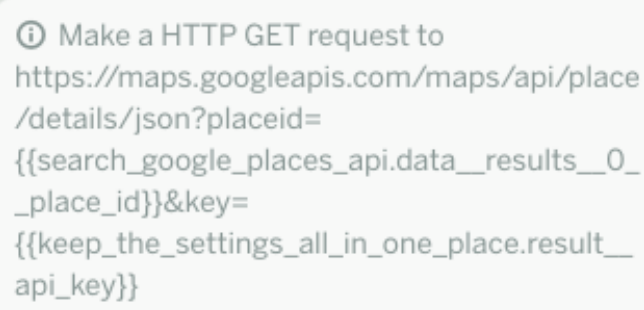

Gambar 7. Konfigurasi Detail Pos Bantuan

Setelah itu respon yang akan diberikan pengguna harus disiapkan dengan bentuk detail dimana pos bantuan berada. Untuk mendapatkan detail informasi pos bantuan pada gambar 7 diperlihatkan api yang bisa menggenerate. API ini bisa digunakan beberapa kali ketika chatbot akan memberikan detail lokasi sesuai jumlah yang di inginkan. Tetapi pada chatbot CEPAT lokasi yang diberikan hanya 3 lokasi terdekat.

\subsection{Hasil dan Pembahasan}

Setelah selesai dengan implementasi hasil dari chatbot CEPAT yang sudah dikonfigurasi langsung bisa diakses pada platform yang disediakan. Pada telegram chatbot CEPAT dapat diakses melalui link https://telegram.me/cepat_evakuasibot atau bisa di add di @cepat_evakuasibot lalu pada facebook messenger pada link: https://m.me/104833631065985 dan terakhir pada website diakses di link: https://fxo.io/m/mj7vge2q. Dan chatbot CEPAT dapat digunakan untuk memberikan informasi pos bantuan terdekat seperti pada contoh berikut menggunakan telegram. 


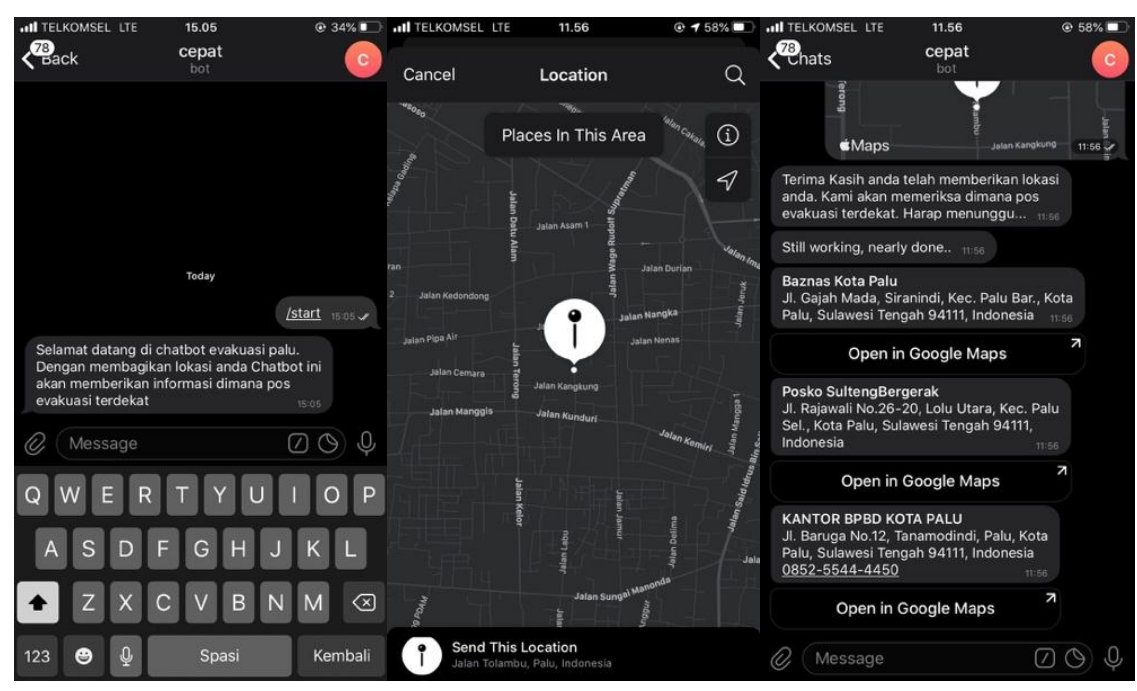

Gambar 8. Hasil Chatbot CEPAT

Pada gambar 8 ditunjukan bahwa chatbot sudah berjalan dengan baik sesuai dengan arsitektur yang dibuat. Chatbot dapat menerima inputan berupa share location selanjutnya chabot dapat memproses inputannya dan hasil yang diberikan dapat menunjukan bahwa dilokasi terdekat pengguna ada Bazanas Kota Palu, Posko SultengBergerak dan Kantor BPBD Kota Palu. Artinya knowledge base dapat diakses sesuai dengan share location dan keyword yang sudah diinput dan diatur. Semua hasil dari implementasi menandakan bahwa chatbot CEPAT dapat memenuhi perancangan arsitektur dan pemodelan percakapan yang sudah dibuat.

\section{Conclusion}

Begitu besarnya bencana di Palu membuat penanganan bencana begitu penting. Penanganan yang cepat tanggap mengenai evakuasi korban bencana menjadi sesuatu hal yang penting. Informasi evakuasi biasanya akan sangat sulit diakses karena call center akan sangat sibuk dengan pelayanan yang terbatas dengan Sumber Daya Manusianya. Dengan menggunakan chatbot CEPAT untuk evakuasi korban bencana di Palu, pemberian informasi posko evakuasi dapat diberikan dengan maksimal. Pembuatan Chatbot CEPAT dapat dicapai dengan analisis NLP dan LBS. Penelitian ini membuat CEPAT dapat diakses melalui media chatbot yang disediakan, lalu dengan hanya memberikan share location pada media tersebut secara otomatis CEPAT akan memproses informasi tersebut menjadi kordinat yang berguna dengan NLP. Lalu kordinat ini akan disematkan dengan keyword khusus yang sudah disematkan. Lalu LBS akan memproses inputan tersebut sehingga bisa memberikan informasi lokasi posko evakuasi yang paling dekat dengan lokasi pengguna.

\section{References}

[1] F. Wex, G. Schryen, S. Feuerriegel, and D. Neumann, "Emergency response in natural disaster management: Allocation and scheduling of rescue units," Eur. J. Oper. Res., vol. 235, no. 3, pp. 697-708, 2014.

[2] V. Nomor and A. D. A. N. Penanggulangan, "The indonesian journal of politics and policy (ijpp)," vol. 1, pp. 83-93, 2019.

[3] R. A. Hadiguna, I. Kamil, A. Delati, and R. Reed, "Implementing a web-based decision support system for disaster logistics: A case study of an evacuation location assessment for Indonesia," Int. J. Disaster Risk Reduct., vol. 9, pp. 38-47, 2014.

[4] I. S. Wekke, Z. Sabara, M. A. Samad, A. Yani, R. Umam, and M. U. Palu, "EARTHQUAKE, TSUNAMI , AND SOCIETY COOPERATION : EARLY FINDINGS IN PALU POST OF

Location Based Service for improving Chabot Disaster Management Evacuator Palu (Muhammad

Syaifur Rohman) 
[5] "PETA PERSEBARAN TITIK KUMPUL GEMPA TSUNAMI PALU, DONGGALA 2018." [Online]. Available: http://ugm.id/PetaBencanaPalu2018.

[6] M. Saadatseresht, A. Mansourian, and M. Taleai, "Evacuation planning using multiobjective evolutionary optimization approach,” Eur. J. Oper. Res., vol. 198, no. 1, pp. 305-314, 2009.

[7] M. Dong, H. Li, K. Ota, L. T. Yang, and H. Zhu, "Multicloud-Based Evacuation Services for Emergency Management," IEEE Cloud Comput., vol. 1, no. 4, pp. 50-59, 2014.

[8] O. Alani, Z. Alazawi, R. Mehmood, S. Altowaijri, and M. B. Abdljabar, "A smart disaster management system for future cities," pp. 1-10, 2014.

[9] S. Cresci, M. Tesconi, A. Cimino, and F. Dell'Orletta, “A Linguistically-driven Approach to CrossEvent Damage Assessment of Natural Disasters from Social Media Messages,” pp. 1195-1200, 2016.

[10] M. Imran, P. Mitra, and C. Castillo, "Twitter as a Lifeline: Human-annotated Twitter Corpora for NLP of Crisis-related Messages,” 2016.

[11] G. Shalunts, G. Backfried, and K. Prinz, "Sentiment Analysis of German Social Media Data for Natural Disasters," 11th Int. Conf. Inf. Syst. Cris. Response Manag., no. May, pp. 752-756, 2014.

[12] D. Buscaldi and I. Hernández-Farias, "Sentiment Analysis on Microblogs for Natural Disasters Management: a Study on the 2014 Genoa Floodings," Proc. 24th Int. Conf. World Wide Web, pp. 1185-1188, 2015.

[13] C. Cobb et al., "Designing for the deluge: Understanding \& Supporting the Distributed, Collaborative Work of Crisis Volunteers," Proc. 17th ACM Conf. Comput. Support. Coop. Work Soc. Comput. - CSCW'14, pp. 888-899, 2014.

[14] I. Akgün, F. Gümüşbuğa, and B. Tansel, "Risk based facility location by using fault tree analysis in disaster management," Omega (United Kingdom), 2015.

[15] R. Khudabadi, “A Recent Study on Early Disaster Warning \& Evacuation System on Mobile Phones Using Google Cloud," vol. 02, pp. 501-503, 2015.

[16] P. Debnath, S. Haque, S. Bandyopadhyay, and S. Roy, "Post-disaster situational analysis from WhatsApp group chats of emergency response providers," Proc. Int. ISCRAM Conf., no. May, 2016.

[17] D. Dutta, "Developing an Intelligent Chat-bot Tool to assist high school students for learning general knowledge subjects," p. 13, 2017.

TRANSFORMATIKA Vol. 18, No. 1, July 2020 : $114-122$ 